\title{
EXCURSION TO THE COAST NORTH AND SOUTH OF BERWICK-ON-TWEED, COCKBURN I.AW, THE CHEVIOTS, AND THE EILDON \\ HILLS.
}

\author{
Long Excursion, July $28 \mathrm{Th}$ to August 4TH, 1903. \\ Director: J. G. Goodchild, F.G.S. \\ Excursion Secretary: R. S. Herries, M.A., F.G.S. \\ (Rejort by THE DiReCTOR.) \\ St. Abis Head, July $28 \mathrm{TH}$.
}

It rained all day. Nevertheless, nearly all the members took train for Reston, determined not to miss the opportunity of studying the geology of the coast line at Coldingham Shore and St. Abb's. Waggonettes to take the party as far as Coldingham had been engaged, and should have left that village in time to meet them at the station. But the innkeepers, not being used to the ways of the Geologists' Association, had concluded that they wouldn't come. So the party had to walk, beguiling the tedium of the journey by making observations, for which there was abundant opportunity, upon the geological action of rain and rivers.

Arrived at Coldingham Shore, the Director called a halt, and then proceeded to point out and describe the geological features which are displayed in so striking a manner on the shore and in the cliffs close to the north side of St. Abb's House. The oldest rocks exposed there are crushed and contorted greywackes of Silurian age, which are stained red by iron infiltered from the rocks that not long since covered them unconformably. Through the Silurian rocks several small intrusive masses-probably necks - of Devonian age had made their way, and the stumps of these, much worn by the weather and battered by the waves, were seen as rocky islets and sea stacks in front of the party. Some fine rugged cliffs, weathered into many picturesque crags and alive with $\mathrm{Kittiwakes,} \mathrm{rose} \mathrm{as} \mathrm{a} \mathrm{background,} \mathrm{and} \mathrm{terminated} \mathrm{the} \mathrm{view}$ further to the north. These Kittiwake Crags consist of andesite lavas, and they form part of the volcanic pile out of which the headland of St. Abb's has been carved. Coming straight towards the party, from Pettico Wick to the north-west, is a fault which throws the lavas down in the eastern side, and brings to the surface in the west the patch of Silurian rocks, upon whose upturned edges lies, with a violent unconformity, the Basement Conglomerate, whose geological position is at the base of the 
andesite lavas just referred to. This conglomerate forms an outlier at Bells Hill.

The party then wended their way northward in single file, along the narrow path at the edge of the cliff, now and then stopping to admire the varied and highly picturesque coast scenery which came into view, and the beatty of whose features was enhanced, rather than otherwise, by the grey curtain of mist.

Passing Bells Hill, the visitors descended to the bottom of a deep valley which has followed the course of the fault pointed out. The slopes on the west side of this valley were formed by the edges of the Silurian greywackes, recently bared by the removal of the conglomerate whose remains form Bells Hill, and whose easterly dip has led to the present inclination of the surface formed by the edges of the older strata upon which the conglomerate formerly lay. The slopes of the valley on the side of the fault have been carved out of the edges of a pile of andesite lavas, which dip at small angles towards the North Sea. The surface features on the east or right hand of the party, therefore, were quite different in character from those on their left. Furthermore, the differences caused by the dissimilarity of petrographical characters were rendered still more striking by the effects of glacial action, for the ice of the Age of Snow has ploughed great furrows over the face of the rock, and has left marks on a large scale in other ways.

After a walk of about a mile, the party reached a small eminence near the coast-line at Pettico Wick. All eyes then spontaneously turned to the north-west in silent admiration of the magnificent line of cliffs displayed before them. In the extreme distance, half hidden by the veil of mist, was seen Brander and Fast Castle, reminiscent of the Bride of Lammermoor. Nearer to the party, the cliffs formed almost every possible variety of small headlands and bays, with only here and there a narrow strip of shingle as a foreshore.

The almost incessant rain had brought out all the streams, so that all those which made their way from inland to the coast were swollen to small torrents, and leaped over the cliffs to the sea in a succession of waterfalls, many of which were large enough to bear comparison with the Fosses of Norway.

The joints and other divisional planes of the rocks, facing in every imaginable direction, imparted an exceptional variety of detail to the faces of the cliffs, while the large number of seafowl which haunt this wild part of the coast added not a little to the interest of the very wonderful panorama which lay before the party.

After a time the Director pointed out and described, with the aid of field diagrams, the chief points of geological interest displayed in this long line of contorted Silurian cliffs, and then the party descended to the shore at the Wick, where the petro- 
graphical characters of the Silurian rocks on the west side of the fault, and of the Caledonian Old Red Andesite lava on its east or downward side, were studied in some detail.

Then the climb to the top of the cliffs in the direction of the lighthouse was begun, the Director calling one or two halts on the way up in order to point out features that were likely to be of interest. Amongst these the history of the valley that extends from Coldingham Shore to Pettico Wick was noticed. The valley nearly separates the headland of St. Bees from the mainland, and the depression forms two inosculating valleys, whose common watershed lies close to Pettico Wick. This is also the seaward extension of the watershed between the Basin of the Forth and that of the Tweed, which runs thence nearly due west as far as the borders of Haddingtonshire. The steep brae between the Wick and the ruined Culdee chapel near the lighthouse was covered with a widespread mantle of Erica cinerea, whose rich crimson blossoms formed a beautiful loreground to the grey exposure of sea and cliff to the north.

The journey was then continued along the edge of the cliffs, which rise abruptly to between 200 and 300 feet above the sea. As they consist almost entirely of andesite lavas, only gently inclined towards the sea, their mode of weathering and their aspect in general stood out in most striking contrast to the features presented by the Silurian cliffs to the north. The headland is riddled in all directions by sea caverns of all dimensions and in all stages of formation. Many of these have had their roofs blown off during storms of exceptional severity, and the caves and sea inlets that have then arisen are, in their own way, in no degree of lesser interest than the coast features already noticed. Most of the walls of these sea inlets are the abode of great variety of seafowl, whose several communities, each by themselves, attracted much attention from the visitors. One solitary gull, which had recently left the nest to fend for itself, remained close to the party for some time while hammers were plied in the endeavour to extract some small agates from among the amygdules of the andesite lavas. The forlorn and lonely aspect of the bird seemed to strike many of the party. The Director made a mental note of the bird's plumage, and described it afterwards to Mr. Geo. Bolam, of Berwick, who expressed a suspicion that it might be an immature Common Gull. If that were the case this would be the first recorded instance of this bird breeding south of its usual habitat.

Near the lighthouse the Director called attention to a wellmarked glaciated rock surface, upon which the striæ and the glacial grooves run coastwise, as they usually do in the maritime areas from Dunbar southwards. He pointed out this as one of the pieces of evidence which are usually interpreted to be due to 
the deflecting influence of the North Sea Ice at the climax of the Age of Snow.

Returning in the direction of Coldingham Shore the party stopped for a few minutes to search for agates amongst the débris of one of the inland cliffs. Then a move was made to the small sea inlet known as "Horsecastle Bay," where lunch was disposed of, standing, with umbrellas up. Afterwards another small cove to the south was visited, and a few of the party whose enthusiasm had not been yet fully quenched by the incessant rain, made further geological explorations. The majority went to the foreshore north of St. Abb's House, referred to at the beginning of this report. Finally, the rocky islets around the harbour at Coldingham Shore were visited. After that the return journey to Coldingham was commenced. Here fluid refreshments of various kinds were got, and then the party made for Reston Station, mostly on foot, and reached Berwick in due course, none of them much the worse for their thorough drenching.

\section{The Cheviot Hills.}

JULY 29 TH.

As the rain had, for a time, ceased to fall, the party set off in waggonettes for Wooler; the route being about sixteen miles, nearly due south, keeping the Cheviots in sight all the way. Most of the country traversed rises but little above the 400 feet contour, and may, indeed, be regarded as part of a plain gently inclined from the Cheviots, and towards the north-east. This lowland area is shaped out of rocks of Lower Carboniferous age, whose higher members, generally speaking, may be said to occur nearer the coast, and whose lower form zones around the Cheviots. The presence of numerous small coal pits along much of the route indicated the outcrop of the Scremerston Coal Series, which is contemporaneous with the lower part of the true Yoredale Rocks of the North Riding of Yorkshire. The Fell Sandstones occur beneath these Scremerston Coals; hence, after leaving the tract of country characterised by the presence of pit-heaps and old collieries, the party traversed a zone of a more hilly nature, mostly given over to pasturage, or left as rough moorland. At Doddington the lowest beds of the Fell Sandstones give rise to a small escarpment, which overlooks a wide lowland tract formed by the outcrop of the Ballagan Beds (Lower Limestone Shale). This outcrop has been followed for several miles by the River Till, which has here at one time formed a lake, ${ }^{*}$ and the river now pursues a winding course north-west- 
ward through the broad lacustrine alluvium deposited under the former conditions.

The party left the conveyances at Wooler, and then walked southward, between the flanks of the Cheviots and the edge of a colony of Eskers, to Middleton Hall, and from there up the rising ground in the direction of the watershed. Presently the Director called a halt, and proceeded to give an outline of the history of the features before the party. He said that the smooth, dome-shaped, almost cragless, character of the hills was due to the fact that nearly all the rocks composing them possess about equal degrees of durability. They are mostly andesite lavas, with some dykes of porphyrite and elvan, and with an inner core of granophyr ic pyroxene granite.

The Cheviot massif has a somewhat complicated history. The denuded surface of the Caledonian Old Red volcano was unconformably covered by the Upper Old Red Sandstone, which was overlapped to a small extent by the Lower Carboniferous Rocks. This complex in turn was again upheaved and denuded, and then covered again, this time by the New Red and subsequently by the Jurassic Rocks. In times much later, perhaps during the Miocene Period, the tract now represented by the Cheviot Hills formed the most elevated part of an area of upheaval. Rain and rivers, afterwards operating for a long time upon the dome thus formed, have eventually laid bare the core. Variations in the relative power of resistance offered by the different stratigraphical envelopes thus exposed have led to modification of the courses pursued by the rivers, as they have cut their way downward from their original channels to those they occupy at present.

The Cheviots appear to have formed an independent glacial centre throughout the greater part of the Age of Snow, though the land ice coming from the west as well as the North Sea Ice on the east, have both left marks of their former presence upon the flanks of the Hills. In the later part of the period glaciers occupied the heads of the valleys, and they left their moraines in the valleys here and there for a few miles outward from the chief centres of niveal precipitation. One such accumulation had partly filled the old valley just below the junction of the Harthope and Carey Burns, and had evidently given rise to a series of moraine-dammed lakes. As soon as the climate changed so that the winter accumulations of snow began to lessen in summer, so that the glacier receded and eventually died away, the Harthope and Carey Burns resumed their work, and gradually cut their way downward through the morainic barrier, draining the old lake step by step, and leaving a series of terraces carved out of the glacial débris, as witnesses of their former existence.

After noticing the features described, the party moved on past "Skirlnaked" to the foot of Carey Burn. Here the first 
object that attracted attention was a dyke of porphyrite, ${ }^{*}$ over which a foot-bridge crosses the burn. This dyke traverses the andesite lavas within that part of the old volcano which the Director referred to as the Zone of Intrusion. Following the Carey Burn upwards, the members came upon several excellent exposures of the andesite lavas, all of them more or less thermometamorphosed. The Director explained this condition of the lavas as being probably due to the gradual rise of the geoisotherms, and, consequently, of sub-plutonic conditions, within the volcano as the cone enlarged by the successive deposition of lava streams at the surface. Higher up the stream several other dykes and sills of porphyrite were met with. The lithological characters of one of the largest of these sills, which is in Carey Burn, just below the foot of Broadstruthers Burn, have been described by Kynaston (Trans. Edin. Geol. Soc., vii, pt. iv, p. 398,1899 ). Specimens of this rock, which is undoubtedly an intrusive mass, were collected by nearly all the members. After carefully examining this porphyrite sill, the party followed up the Common Burn, attentively noting the gradual change in the character of the lavas as they went. On nearing the part where the granite appears in the burn, it was observed that the lavas had become more changed in character, and it was evident that the metamorphism had gradually increased in that direction, until, eventually, exposures of the altered lavas were met with which had become holocrystallıne and quite undistinguishable from the porphyrites. The Director called special attention 10 this feature, which, he said, was oue of common occurrence within the inner and older portions of a volcanic cone. $\mathrm{He}$ referred to this as the Zone of Reconstruction. He regarded the change as due to hydro-thermal conditions, consequent upon the uprise of the geo-isotherms as the dimensions of the volcanic cone increased. He thought that these conditions permitted of the gradual softening of each of the constituents of the lavas, one after the other, in the reverse order to that of their original consolidation. Then followed, when the volcano was quieting down, their reconstruction in a crystalline form. Hence, he thought, a rock of volcanic origin acted upon in this way might eventually assume an aspect similar to that of one formed under trappean or even under plutonic conditions. He thought that many gabbros had been formed in this way from basalt lavas, dykes, and sills.

Farther up the stream, the granite itself was met with. Its composition, as well as its petrographical and lithological characters, did not, the Director thought, favour the idea that it represented an extreme stage of the kind of reconstruction to which the porphyrite-like state of the altered lavas was due. He

\footnotetext{
- It should be noted that the term Porphyrite is here employed for the trappean equivalents of the volcanic andesites and the plutonic diorites.-J. G. G.
} 
thought that the granite was due rather to the transmutation of the andesitic rocks forming the older parts of the core of the volcano, and that the change was due to the uprise of a more acid and potash-bearing magma within what he termed the Zone of Transmutation. He thought that the frequent association of granophyric granites with gabbros could be also explained in this manner, as well as the phenomena presented by composite dykes.

After making a careful study of the facts, and collecting specimens, the party began the return journey across the moor between the Common and Broadstruthers Burns, and then over the hill north of the head of Carey Burn to Earle, and thence back to Wooler.

\section{Burnmouth.}

JULY зотн.

The journey by rail from Berwick northward to Burnmouth carries one close to the edge of the cliff and affords many interesting views of the North Sea and of the coast features, which were to be studied in detail by the party during the day. About half-way on the Border of Scotland was passed, not far from Lamberton Toll, which was long the representative on the east of Scotland of Gretna Green.

Arrived at Burnmouth Station the party made for the small valley which has been carved out of the cliff and which leads to the shore there. In this, and around it, are to be seen very fine examples of the folded, contorted, and often reversed, beds of Greywacke which mainly form the Silurian Rocks of this part. Here and there these rocks are seen to be traversed by dykes of porphyrite, similar in lithological character to those which had been previously examined in the Cheviots, and, like them of Devonian Age, although formed long anterior to the Upper Old Red, which may be seen in many places to cover these unconformably. On the way down the gully a discussion arose regarding the origin of some remarkable surface markings on the face of one of the Greywackes pointed out by Captain Norman. No definite conclusion as to how they were formed was arrived at.

At the foot of the gully the party turned northwards along high-water mark and made their way, after much scrambling and climbing, to the Breeches Rock, which has been formed by the action of the sea upon a dyke of porphyrite intruded into the Silurian strata. The Gull Rock, an equally striking feature, and the chosen resort of various sea-fowl, especially the Herring Gull and Lesser Black-Backed Gull, also attracted much attention, as did the magnificent line of cliffs formed by the Silurian Rocks to the north of that. These cliffs are shaped out of bent Proc. Geol. Assoc., Vol. XVIII, ParTs 5 aND 6, I904.] 
and inverted beds of Greywacke, folded into isoclines. They form the seaward ends of the great tract out of which the Lammermoors have been carved.

Returning to Burnmouth the party traversed the street occupied by the fisherfolk, and then examined the foreshore close to the Harbour, where the great maritime boundary fault which limits the Silurian Rocks is seen. At this point the fault has a throw of something more than two thousand feet down on the east, and brings soft sandstones, clays, shales, and beds of impure limestones belonging to the upper third of the Ballagan Beds into vertical contact with the Silurian Rocks. If the top of the cliff represents the position of the beds of the Upper Old Red (supposed to have been but recently denuded) the throw will amount to that stated.

A fine section of these rocks is seen in the cliff face terminating seaward at Ross. The beds are slightly inverted near the fault, and are at high angles nearly all the way. They consist of soft sandstones, grey, sage-green, and dull-chocolate clays and shales, with some few bands of the so-called "cement stones." These rocks appear to graduate upwards south of Ross into the Fell Sandstones.

The party next took the path along the top of the cliff, under the guidance, for the time, of Captain Norman ; and then went to a cutting near Hilton. Here was seen a conglomerate, regarded as Upper Old Red, which lies unconformably upon Silurian rocks traversed by a porphyrite dyke. The contents of the conglomerate were carefully searched, and many interesting blocks, including some of porphyrite, and others of granite like that of Cockburn Law, were found. Being near to the powerful fault which skirts this part of the Berwickshire Coast, the pebbles were much slicken-sided, and presented some resemblance to stones which had been glaciated. The Director took these as a text for some remarks concerning glacial markings and slickensides in general, and instanced several cases in which the two form of markings may be seen in sitî in close proximity to each other. He then reminded the party about the large glaciated stone which he and the late Wm. Atkinson got out of the Brockram (Lower New Red) near Appleby, on the occasion of the visit of the Association to Edenside in 1889 , and which he and others had often referred to since. There were present several members of the Association who saw the glaciated stone got out, and who had no doubt regarding its being truly glaciated; and some indignation was expressed that the record of the find had been publicly called in question within the last year or so.

Leaving this cutting the party advanced to the end of the promontory west of the Lamberton Fishery Station, whence a fine prospect of the cliffs for miles to the north, as well as to the south, could be obtained. The Fishery Station is upon the 
Dun Limestone, which lies just above the top of the Scremerston Coal Series; while the rocks just to the north are near the base of the Fell Sandstone. Hence a fault of considerable magnitude, cutting across the Berwickshire Coast Fault, must come in there. The Director called attention to this, and remarked that it did not appear to have been noticed before. The contrast between the highly inclined Fell Sandstones north of the fault referred to, and the nearly horizontal beds of sandstone above the Lamberton Limestone, which form the cliffs to the south, is very striking, and attracted much attention. The sandstones on either side are much stained by infiltration from the New Red, and the Director expressed the opinion that an outlier of those rocks had existed here, as a faulted-in strip, until quite recently, the last patch to disappear having perhaps been that on the terrace next the cliffs south of Ross.

In a cutting near the Lamberton Fisheries the Director called attention to the occurrence in a bed of sandstone there of some pseudomorphs in Turgite after Pyrites; and several good specimens were got. The Rev. W. Winwood obtained part of a Gyracanthus spine from the same rocks.

Then a return was made to the Great North Road, and some quarries in porphyrites were examined, after which some of the members returned by train, while the remainder walked along the top of the cliffs to Berwick.

\section{Duns and Cockburn Law.}

\section{JULY 3 IST.}

The party went by train viâ Reston, to Duns, and then drove in waggonettes as far as Cumledge. Here, by kind permission of Mr. Wilson, the party were allowed to pass through the grounds to the Whiteadder, on the right bank of which is exposed a clear section of the beds belonging to the lower part of the Ballagan Series (Lower Limestone Shale) which may be faulted in against the Upper Old Red Sandstone. The Ballagan Beds were seen to consist here of shales and clays, mostly slate-colour, but along certain bands, faintly tinged with sage green or with dull maroon. Amongst these strata are impersistent bands of soft sandstone, which here and there show casts of sun-cracks, rain prints, and pseudomorphs of rock salt. Thin bands of an arenaceous dolomite or "cement stone" occur here and there. The beds, not very highly coloured in themselves, are capped by a brightred deposit of glacial origin, in which the colour is due to the greater part of the materials having been derived from the area of Upper Old Red Sandstone lying to the west. No fossils were discovered on this occasion. 
Themembers then followed the banks of the Whiteadder round to Preston Bridge, noting, en route, a second exposure of the Ballagan Beds on the left bank of the river. At Preston Bridge the position of the "Kelso Traps" was pointed out, but not visited. These traps are seen on the right bank of the river a few hundred yards above the bridge, and consist of a bed of basalt lava, with some tuff; both lying close upon the Upper Old Red Sandstone-perhaps with a slight unconformity.

From Preston Bridge the party drove for a mile or so, and then alighted at Primrose Hill. From there a walk across the fields brought them to the banks of the Whiteadder opposite Cockburn Mill, where some time was spent in examining the unconformable junction of the Upper Old Red Sandstone with the vertical or highly-inclined beds of Silurian greywacke, a feature which at once recalled to the members of the Association what they saw at the Siccar Point on the occasion of their visit to Edinburgh. The conglomerate yielded specimens of the granite of Staneshiel Hill which is post-Silurian in age, and is considered to be coeval with the later rocks of Caledonian Old Red Age. Hence, it was seen, an unconformity representing a long period of geological time must exist here, as elsewhere in North Britain, between the Upper Old Red and the older or Caledonian Old Red.

A pleasant walk along the left bank of the Whiteadder took the party over the exposures of Silurian rocks, which are here altered in the contact zone around the granite of Staneshiel Hill into bornfels, containing, as usual, abundant brown mica and some few other contact-minerals.

Various river-terraces, ranging to fifty feet or more above the bed of the Whiteadder, were noted on the way.

'The actual junction of the granite with the Silurian rocks is not exposed, but the party bammered at rocks within a few feet on either side of it. The granite was seen to consist of the type usual in connection with the andesite lavas of the Caledonian Old Red. Plagioclase felspar predominates, muscovite is absent, and the ferro-magnesian minerals, chiefly biotite and hornblende, include a small percentage of pyroxene. Sphene, Allanite, and Apatite occur as accessories. The Director thought that the rock was of the kind that might have arisen through the assimilation of an earlier andesitic mass by a later magma containing a higher percentage of potash and silica within what he termed the Zone of Transmutation. Hence the granite is of later date than most of the lavas and porphyrites which arose in connection with the same vent.

A large dyke-like mass, of a basic type, belonging to a later cycle of eruptive action, traverses the granite, and is well seen in the river course. The party stopped for lunch near this.

The features that attracted attention on the journey for 
nearly a mile above the basic intrude just referred to, were some striking examples of old river terraces, which showed that the Whiteadder must have cut its bed downward through a thick deposit which half filled the older gorge excavated by the river between Staneshiel Hill on the one bank and Cockburn Law on the other. Although the material that had thus filled the gorge was of lateglacial age the evidence that it represented a moraine was not quite clear.

Following the bank of the river, the party came upon several excellent examples of the dykes of porphyrite which cut the Silurian rocks here. These are the trappean equivalents of the andesite lava of Caledonian Old Red age which are supposed to have formerly covered the Silurian rocks of these parts, and which are violently unconformable to these rocks as well as to the later Upper Old Red Sandstone.

A picturesque and well wooded gorge cut by the river through the ends of the highly-plicated Silurian greywackes, led to the old copper mines at Ordweel, at the turn of the river opposite the house called Elba. The copper ore consists merely of some superficial films of Chrysocolla, which, being of a bright green, have led to the belief that copper ore would be found in paying quantities, which did not prove to be the case.

Crossing the beautiful gorge at Ordweel by the foot-bridge which spans it near Elba, the party began the return journey along the road which runs along the right bank of the Whiteadder. This, being at a considerable elevation above the bed of the river, afforded the party an opportunity of taking a more comprehensive view of the outward route than could be obtained there. A road-side quarry in the granite of Cockburn Law afforded excellent examples of granite which had decomposed into a mass that could easily be crumbled to fragments between the fingers, but in which the felspars (as is usually the case in the heavily glaciated parts of Britain) are not much kaolinised.

A walk alongside of a tributary of the Whiteadder past a fine exposure of the Upper Old Red Sandstone, which has yielded good examples of Palaopteris hibernica (not obtained, however, by the party) brought the excursionists to the Chain Bridge near Cockburn Mill. Here, as there was still half an hour to spare, some of the party went with Mr. Falconer of Duns to search the exposure of Upper Old Red Sandstone opposite Cockburn Mill for fossils, and were successful in obtaining fragments of Bothriolepis, perhaps $B$. obesus, and scales of Holoptychius.

A pleasant stroll across the lowlands brought the party back to the station at Duns, and thence to Berwick, which was reached at the end of a day which had been exceptionally fine. 


\section{The Eildon Hilis.}

Avgust rST.

Train was taken as far as Newton St. Boswells, and the party walked thence across the fields and through the woods near Fildon Hall to the north-eastern summit of the Eildon Hills. Before climbing the east and steepest part of the hill the party stopped at an old quarry in which an intrusive mass of a bemicrystalline rock having a composition intermediate between that of an andesite and a trachyte, and showing a well-marked flowstructure, was examined. This rock is clearly seen to cut across the Upper Old Red Sandstone strata, and is, therefore, not a lava. Portions of the sandstone still remaining within the mass were seen.

Arrived at the summit the Director prepared, with the aid of maps and diagrams, to give an account of the geological features visible from that point, and especialiy to the very remarkable series of great north-easterly grooves into which the surface of all the rocks has been carved by the erosive action of a moving sheet of land ice.* But showers of rain began to fall, and although the effects produced by the mists and the rainclouds upon the landscape between each shower interested the party for half an hour or so, the increasing downpour eventually drove them from their position, and sent most of them in a state of discomfort back to the train.

\section{SCREmerston.}

\section{AUGUST 3RD.}

The distance to be traversed being short, and the startingpoint close at hand, the party walked from Berwick by way of the Old Border Bridge to Tweedmouth. Close to the Waterworks at Tweedmouth the Director called a halt. Mr. Whitaker then drew attention to the stream of muddy water off the mouth of the Tweed, which could be seen to be carrying the subaerial waste from Tweedside outwards for a mile or more into the clearer water of the North Sea. The Director then gave an outline of the geological features around where the party stood, using the Geological Survey Maps for the purpose of further illustrating these points, and paying a tribute to the work done by the late Mr. Wm. Gunn in that connection. At the point where the remarks were made the rock at the surface was part of the Fell Sandstones, into which, close by, a well had lately been sunk to a depth of 246 feet, which had furnished most of the water supply for the town of Berwick. Except within the City of

*See J. G. Groodchild on "Glacial Furrows," in the Glacialists' Magazine, vol. iv, Part I, which however, were printed without the author seeing a proof. 
Edinburgh, this well appears to be almost the only one north of the Midland Counties of England which has been sunk more than a few feet into the solid rock for purposes of water supply. The dip here is east-north-easterly, at first at small angles, and then at higher inclinations. Hence the Scremerston Coal Series comes on near the mouth of the Tweed, and its higher beds run through the eastern half of the town of Berwick, and are succeeded by the limestones which extend northward from the Pier. The Scremerston Coal Series forms the coast-line on the south side of the Tweed for more than two miles south of Berwick, striking gently inland, so that successively higher beds come on as the coast is followed from Tweedmouth southeastward.

The Scremerston Coal Series were then examined in some detail, and eventually the several limestone beds, shown in the sections given in the Handbook, were also studied and searched for fossils. The limestones referred to were, first, the Dun Limestone, then the Woodend Limestone, and next the two above the last, which, it may be remarked, appear to represent the top bed of the Mountain Limestone as defined by Professor Phillips, and as it occurs in the typical area which includes Wensleydale in north-west Yorkshire and the dales adjoining; then the lower limestones of the Yoredale Rocks of Phillips (which have little relationship with much of the so-called "Yoredales" of the area from Clitheroe southwards). Various quarries have been opened in these Yoredale Limestones near Scremerston, and they are well displayed also in many good coast sections there. Considerable attention was devoted to these by the party. The Director called attention to the local dolomitisation of the limestones, and pointed out that here, as elsewhere, this feature must be regarded as evidence of the presence, in recent geological times, of the New Red Rocks, and, therefore, also of the Rhætic and the Jurassic Rocks, on the ground that, wherever the New Red occurs, it has been conformably succeeded by the rocks referred to.

On one part of the coast the limestone bed has been locally pinched up into sharp folds. The same kind of feature occurs at several other points, notably at the "Saddle Rock," near Dunstanburgh Castle, at Ardross in Fife, near Dunbar, and, the Director thought, also in the Chalk Cliffs at Flamborough Head. He thought that in all these cases the folds were quite superficial, and were of the same nature as Clement Reid's Fold in the Chalk at Trimingham, and were, he thought formed by the impact of the ice which filled the North Sea at the climax of the Age of Snow.

After a successful hunt for fossils amongst the limestones in the Scremerston quarries the Director summarised the chief points of interest in the section just visited, with special reference 
to the correlation of the rocks with those of the Craven district on the one hand and the Lower Carboniferous rocks of Edinburgh, as he had done on the occasion of the visit of the Association to that city in 1897 .

The return journey was begun in sufficient time to enable those who wished to do so to gather examples of the pretty agates which occur in the beach shingle and which have been carried there from the Caledonian Old Red andesitic lavas of the Cheviots.

\section{Eyemouth.}

AUGUST 4 TH.

Bright sunshine and an almost cloudless sky characterised the concluding day of the memorable Long Excursion of 1903 . The party took train to Burnmouth, and thence again by the local line to the picturesque fishing town of Eyemouth. A walk through its intricate labyrinth of short streets brought the party to the harbour, and thence along the shore northward in the direction of the "Fort." The first geological feature to attract attention was a mass of agglomerate, which appears to represent one of the " necks" from which the volcanic rocks of the Caledonian Old Red have been driven to the surface. The large size of some of the ejected blocks included in the agglomerate bore eloquent witness to the violent action of the later eruptions from these vents. Then a cliff section on the west was pointed out. The lower part is shaped out of the volcanic rock just referred to, and above that occurs a mass of loosely-aggregated material of glacial origin. Cutting through this was seen the cross section of an old valley, which, in turn, was filled with an accumulation of later date. From the base of this Mr. John Smith, of Kilwinning, obtained a small boulder of metamorphic rock similar to those of the type common in the Southern Highlands of Scotland.

Going north-eastward along high-water mark, the party came to the foot of the cliff below the "Fort," in which the upper part at the seaward end consists of the sandstones and conglomerates of the Upper Old Red, which are here to be seen lying unconformably upon the volcanic rocks of the Caledonian Old Red just referred to. The section is of special interest as being one of the very few in which the actual junction is seen. The field evidence regarding this unconformity is, however, perfectly clear, and it shows that two of the greatest unconformities in the whole of the British geological series are these which occur, respectively, below and above, the Caledonian Old Red. After some remarks from the Director to this effect the party went to the top of the cliff, where scenery of great beauty and much geological interest 
met their eyes. Attention was called to the fine series of caves by which the sea made its way inland. The long line of remnants of the higher raised beaches, which formed the tops of the cliffs both northward and southward of the party, was commented upon.

After the Director had given a summary of all the chief points of geological interest connected with the places visible from the standpoint of the party, a move was made for the station, and the Long Excursion of r 903 came to an end.

\section{REFERENCES.}

Geological Survey Maps :

England: Sheets 108 (N.E.) and 110.

Scotland: Sheets $25,26,33,34$.

I 858. TATE, GEORGE.- "The Geology and Archæology of Beadnell, in the County of Northumberland." Trans. Berw. Nat. Club, vol. iv, p. 96.

1883. TEalL, J. J. H.- "Notes on the Cheviot Andesites and Porphyrites." Geol. Mag., Dec. 2, vol. X, pp. 100, 145, and 252.

1883. Tealt, J. J. H.- "On Hypersthene Andesite." Geol. Mag., Dec. 2, vol. $x, p .344$.

I884. LEBOUR, G. A.- "Geology of Northumberland and Durham."

1885. TEALI, J. J. H._" On some Quartz-Felsites and Augite-Granites from the Cheviot District." Geol. Mag.. Dec. 3, vol. ii, p. Io6.

1888. Clough, C. T.- "The Geology of the Cheviot Hills." Mem. Geol. Survey.

I888. MiLLER, Hugh.- "On the classification of the Carboniferous Limestone Series, Northumbrian Type." Proc. Berw. Nat. Club, vol. xii, p. I 16.

1897. GoodchiLD, J. G.-" An Outline of the Geological History of the Rocks around Edinburgh." Proc. Geol. Assn, vol. xv, p. II 7 .

1899. GunN, W.- "Notes on the Rocks about Berwick-on-Tweed." Trans. Berw. Nat. Club, vol. xvi, No. 3, p. 313.

1899. GunN, W.-- "Notes on the Correlation of the Lower Carboniferous Rocks of England and Scotland." Trans. Geol. Soc. Edin., vol, vii, pt. iv, p. $36 r$.

1899. KYNASTON, HERBERT.- "Contributions to the Petrology of the Cheviot Hills." Trans. Edin. Geol. Soc., vol. vii, pt. iv, page 390. 